\title{
Forests, savannas, and grasslands: bridging the knowledge gap between ecology and Dynamic Global Vegetation Models
}

\author{
M. Baudena ${ }^{1}$, S. C. Dekker ${ }^{1}$, P. M. van Bodegom ${ }^{2,3}$, B. Cuesta $^{4}$, S. I. Higgins ${ }^{5}$, V. Lehsten ${ }^{6}$, C. H. Reick ${ }^{7}$, \\ M. Rietkerk ${ }^{1}$, S. Scheiter ${ }^{8}$, Z. Yin ${ }^{9}$, M. A. Zavala ${ }^{4}$, and V. Brovkin ${ }^{7}$ \\ ${ }^{1}$ Copernicus Institute of Sustainable Development, Environmental Sciences Group, Utrecht University, \\ 3508 TC Utrecht, the Netherlands \\ ${ }^{2}$ VU University Amsterdam, Department of Ecological Science, de Boelelaan 1081, \\ 1081 HV Amsterdam, the Netherlands \\ ${ }^{3}$ Leiden University, Institute of Environmental Sciences, Einsteinweg 2, 2333 CC Leiden, the Netherlands \\ ${ }^{4}$ Forest Ecology and Restoration Group, Department of Life Sciences, Ctra. Madrid-Barcelona km. 33.6, \\ University of Alcalá, 28805 Alcalá de Henares, Madrid, Spain \\ ${ }^{5}$ Department of Botany, University of Otago, P.O. Box 56, Dunedin 9054, New Zealand \\ ${ }^{6}$ Department of Physical Geography and Ecosystem Science, Lund University, Sölvegatan 12, 22362 Lund, Sweden \\ ${ }^{7}$ Max Planck Institute for Meteorology, Bundesstr. 53, 20146 Hamburg, Germany \\ ${ }^{8}$ Biodiversity and Climate Research Centre (LOEWE BiK-F), Senckenberg Gesellschaft für Naturforschung, \\ Senckenberganlage 25, 60325 Frankfurt am Main, Germany \\ ${ }^{9}$ Institute for Marine and Atmospheric research Utrecht, Utrecht University, Utrecht, the Netherlands
}

Correspondence to: M. Baudena (m.baudena@uu.nl)

Received: 13 May 2014 - Published in Biogeosciences Discuss.: 17 June 2014

Revised: 23 February 2015 - Accepted: 27 February 2015 - Published: 20 March 2015

\begin{abstract}
The forest, savanna, and grassland biomes, and the transitions between them, are expected to undergo major changes in the future due to global climate change. Dynamic global vegetation models (DGVMs) are very useful for understanding vegetation dynamics under the present climate, and for predicting its changes under future conditions. However, several DGVMs display high uncertainty in predicting vegetation in tropical areas. Here we perform a comparative analysis of three different DGVMs (JSBACH, LPJ-GUESSSPITFIRE and aDGVM) with regard to their representation of the ecological mechanisms and feedbacks that determine the forest, savanna, and grassland biomes, in an attempt to bridge the knowledge gap between ecology and global modeling. The outcomes of the models, which include different mechanisms, are compared to observed tree cover along a mean annual precipitation gradient in Africa. By drawing on the large number of recent studies that have delivered new insights into the ecology of tropical ecosystems in general, and of savannas in particular, we identify two main mechanisms that need improved representation in the examined DGVMs.
\end{abstract}

The first mechanism includes water limitation to tree growth, and tree-grass competition for water, which are key factors in determining savanna presence in arid and semi-arid areas. The second is a grass-fire feedback, which maintains both forest and savanna presence in mesic areas. Grasses constitute the majority of the fuel load, and at the same time benefit from the openness of the landscape after fires, since they recover faster than trees. Additionally, these two mechanisms are better represented when the models also include tree life stages (adults and seedlings), and distinguish between fire-prone and shade-tolerant forest trees, and fire-resistant and shade-intolerant savanna trees. Including these basic elements could improve the predictive ability of the DGVMs, not only under current climate conditions but also and especially under future scenarios. 


\section{Introduction}

Savannas cover about a fifth of the Earth's land surface, and have wide socioeconomic importance regarding land use and biodiversity (Scholes, 2003). Savannas are the central biome in the transition between grasslands and forests, and they are characterized by the coexistence of two types of vegetation: trees (i.e., woody vegetation), and grasses (i.e., grasses and herbs). In most of the savanna ecosystems, we observe highly shade-intolerant and fire-tolerant $\mathrm{C}_{4}$ grasses and $\mathrm{C}_{3}$ trees. This savanna definition is generally valid, with the exception of a few regions (e.g., the Neotropical cerrado where $\mathrm{C}_{3}$ grasses dominate, see Lloyd et al., 2008; Ratnam et al., 2011). For a long time, ecologists have been fascinated by savannas because trees and grasses coexist, while competing mainly for the same resource, namely water, which is the main limiting factor (Sankaran et al., 2004; Scholes and Archer, 1997; Walter, 1971). Classical ecological theory, such as the competitive exclusion principle, predicts that only one vegetation type can survive in these conditions (Hutchinson, 1961; Tilman, 1982). To solve this conundrum, numerous experimental and modeling studies have explored the nature of tree-grass competition and coexistence (e.g., Higgins et al., 2000; House et al., 2003; Sankaran et al., 2004; Scholes and Walker, 1993; Walker and Noy-Meir, 1982). Grasses can outcompete trees in the driest environments, where tree growth is water limited (Higgins et al., 2012), and they have a particularly strong competitive effect on tree seedlings, as grasses and tree seedlings compete for water in the same surface layer (Baudena et al., 2010; Bond, 2008; February et al., 2013; Sankaran et al., 2004; Wakeling et al., 2011; Yin et al., 2014b). In less arid conditions, however, adult trees can potentially grow deeper roots and reach deeper water than grasses (Kulmatiski and Beard, 2013; Walter, 1971; Ward et al., 2013), although overlap between grass and tree roots can be high in some savannas (e.g., February and Higgins, 2010; Higgins et al., 2000; House et al., 2003).

In addition to water availability, fire is an important driver of tree-grass dynamics. $\mathrm{C}_{4}$ grass biomass enhances fire spread in open ecosystems due to its high flammability. At the same time, grasses benefit from fire because they recover faster than trees, and benefit from the open spaces after fire, thus creating a positive feedback mechanism that enhances savanna formation and presence (as shown by long-term fireexclusion experiments, Higgins et al., 2007, or model studies, e.g., Higgins et al., 2008; van Langevelde et al., 2003; see also Hoffmann et al., 2012). Fires may also limit tree seedling recruitment and growth, thus reducing tree dominance further (e.g., Hanan et al., 2008; Higgins et al., 2000). This grass-fire feedback is characteristic of tropical savannas and grasslands, while in most of the other biomes woody species produce most fuel for fires (e.g., boreal forests, Bonan and Shugart, 1989). Fire is essential to savanna persistence in wetter areas, which would be forested otherwise. The grass-fire feedback is reinforced by the differences be- tween savanna and forest trees. In contrast to savanna trees and grasses, forest trees are fire-prone and shade tolerant, adapted to persist in conditions of low light availability and in the absence of fire (Ratnam et al., 2011; Rossatto et al., 2009). Thus, when fires are absent and water supply is sufficient, forest trees outcompete grasses and savanna trees because of light limitation, while if fires are active, savanna trees persist but fires and shade intolerance limit their cover, keeping savannas open (Hoffmann et al., 2012). This feedback, which we define as the "vegetation-fire feedback", and which is an extended description of the abovementioned grass-fire feedback, possibly leads to bistability of forest and savanna in mesic regions (e.g., van Nes et al., 2014; Staver and Levin, 2012).

Savannas are expected to undergo major changes in the future due to increasing temperature and $\mathrm{CO}_{2}$ concentration, modified rainfall patterns, and subsequently changed variability in fire regimes (Intergovernmental Panel on Climate Change - IPCC, 2007). In recent years, an increase in woody cover has been observed in savannas all over the world (e.g., Bowman et al., 2010; Buitenwerf et al., 2012; Donohue et al., 2013; Ward, 2009; Wigley et al., 2010). Several studies tried to explain wood expansion by overgrazing or decreasing fire frequency, which would enhance grass mortality and thus favor woody vegetation (Scholes and Archer, 1997). However, $\mathrm{CO}_{2}$ increase is probably one of the main causes of woody encroachment, leading to savanna expansions (e.g., at the expense of grasslands). As water use efficiency increases with $\mathrm{CO}_{2}$ (e.g., de Boer et al., 2011), thus decreasing the water needed for growth, increased $\mathrm{CO}_{2}$ concentration leads to a shift in tree-grass competition for water, possibly favoring $\mathrm{C}_{3}$ trees over $\mathrm{C}_{4}$ grasses (Bond and Midgley, 2000; Bowman et al., 2010; Kgope et al., 2010; Polley et al., 1994; Wigley et al., 2010). In African savannas, paleo-ecological evidence from the last glacial period, as well as observations of the last 50-100 years, suggests that increasing $\mathrm{CO}_{2}$ coincides with an increase in savanna woody plant growth (Bond et al., 2003; Scheiter and Higgins, 2009). These transformations could have larger effects on global biogeochemical cycles and precipitation than for any other biome due to the large extent and productivity of savannas (IPCC, 2007; Snyder et al., 2004).

Dynamic Global Vegetation Models (DGVMs) are an important tool for understanding large-scale vegetation dynamics, and they are considered important also to study the forest, savanna, and grassland biomes, and their interactions within past, current and future climates (Higgins and Scheiter, 2012; Murphy and Bowman, 2012). Some DGVMs are part of Earth System Models (ESMs), where they describe the interactive role of the Earth's land surface in the climate system. Given their global application, DGVMs necessarily keep the descriptions of vegetation dynamics simple. For example, they represent the enormous plant trait diversity of tropical regions by distinguishing only one or two plant functional types (PFTs). Nevertheless, they realistically reproduce the 
distribution of the majority of the world's biomes (Fisher et al., 2010; Sitch et al., 2003). However, projections of vegetation distribution by DGVMs are often uncertain, especially for the forest, savanna, and grassland biomes (Bonan et al., 2003; Cramer et al., 2001; Hely et al., 2006; Hickler et al., 2006; Sato et al., 2007; Sitch et al., 2008). This is probably a consequence of the fact that most DGVMs were not specifically designed for these tropical systems (House et al., 2003), and thus they do not include the specific internal feedbacks typical of these biomes (Moncrieff et al., 2013). Improving the DGVM representation of ecological processes under present climatic conditions is essential for projecting biome boundary shifts and climate change impacts into the future (Beerling and Osborne, 2006; Murphy and Bowman, 2012; Sitch et al., 2008).

To evaluate why DGVMs may have difficulties predicting the distribution and dynamics of savannas, we will analyze three DGVMs, with a particular emphasis on the representation of what in the following we call the "ecological interactions" between grasses and trees, i.e., the most important tree-grass competition mechanisms, and the feedbacks with their environment. While physiological processes are often included in detail in DGVMs, the ecological interactions are not represented with the same accuracy in many models, despite their potentially large influence on the DGVM outcomes (e.g., Fisher et al., 2010; Scheiter et al., 2013). Reflecting on the current ecological understandings of savannas, we will describe if and how the key mechanisms are included in current DGVMs. We chose to analyze three different DGVMs: JSBACH (Brovkin et al., 2009; Raddatz et al., 2007; Reick et al., 2013), LPJ-GUESS-SPITFIRE (Smith et al., 2001; Thonicke et al., 2010) and aDGVM (Scheiter and Higgins, 2009). JSBACH represents a DGVM as typically used in ESMs (and representative for most models included in the current IPCC coupled model inter-comparison project, CMIP5). LPJ-GUESS additionally includes the demography of PFTs, which is likely to affect competition dynamics, and it includes SPITFIRE, i.e., a new specific module to represent fire dynamics. Finally, aDGVM represents a new class of DGVMs, including functional variation within PFTs (e.g., phenology, allocation, and physiology adapt to changing environmental conditions). The aDGVM was specifically designed for African vegetation and savannas. In the following, we will focus on the African continent, where savannas occupy large areas and where all of the three models have been applied (Brovkin et al., 2009; Hickler et al., 2009; Higgins and Scheiter, 2012; Lehsten et al., 2009; Scheiter and Higgins, 2009). Focusing on one continent also has the advantage that the mechanisms driving the dynamics are more likely to be similar (Lehmann et al., 2014). We will compare the model outputs with observations from field and remote sensing data (Hirota et al., 2011; Sankaran et al., 2005; Staver et al., 2011). We attempt to bridge the knowledge gap between our ecological understanding and the representations of vegetation in global vegetation models. Our aim is to determine which mechanisms need to be included or improved in the representation of ecological interactions of existing DGVMs in the forest, savanna, and grassland biomes, to ameliorate the current vegetation model predictions, as well as their projections under future (e.g., climate change) scenarios.

\section{Methods}

\subsection{Model descriptions}

DGVMs were developed to quantify transient responses of terrestrial ecosystems to past, present and future climates, and this required the inclusion of modeling vegetation dynamics in addition to biogeochemical processes (Cramer et al., 2001; Pitman, 2003; Prentice et al., 2007). To account for processes at the subgrid-scale, DGVMs often assume fractional vegetation cover within the model grid cell (tiling or mosaic approach). Vegetation description is based on PFTs, which aggregate and represent species with similar functions. Biomes are then represented by a mixture of PFTs, such as evergreen and deciduous, broadleaved and needleleaved trees, shrubs, and $\mathrm{C}_{3}$ and $\mathrm{C}_{4}$ grasslands, which dominate in particular climates. Savannas are typically simulated as a mixture of tropical, broadleaved, deciduous trees ("savanna trees" hereafter), and mostly $\mathrm{C}_{4}$ grassland, while forests have mostly tropical, broadleaved, evergreen trees ("forest trees" hereafter).

DGVMs in general have a quite standard set of assumptions to represent plant physiology, including photosynthesis and biomass production. Most of them calculate gross primary production (GPP) by a coupled photosynthesistranspiration scheme, and estimate autotrophic respiration as a function of temperature. Net primary production (NPP) is dependent on the climate and $\mathrm{CO}_{2}$, and scaled up to the plant or PFT level by building up below- and aboveground carbon and leaf area (e.g., Sitch et al., 2003). Processes affecting PFT composition, such as competition for resources, mortality, and demography (i.e., what we call here the ecological interactions), are included in DGVMs as separate modules that interact with the physiological and phenological modules.

For the purpose of this paper, we will focus on the description of how the ecological processes relevant for tropical vegetation dynamics are included in the three selected DGVMs (JSBACH, LPJ-GUESS-SPITFIRE, and aDGVM). Only the physiological aspects relevant for the difference in PFT composition in grasslands, savannas, and forests will be described. JSBACH is part of an ESM and was designed to represent the interactive role of vegetation and land surface in the climate system. While LPJ-GUESS has been included in an ESM in several studies, LPJ-GUESS-SPITFIRE has never been used in such context, and the same holds for aDGVM. Both models are so far used only "offline", i.e., they are 
Table 1. Models and their specifics concerning the tree-grass transition.

\begin{tabular}{|c|c|c|c|c|c|c|}
\hline Model & $\begin{array}{l}\text { Specific for } \\
\text { tropical } \\
\text { vegetation }\end{array}$ & $\begin{array}{l}\text { Variables representing } \\
\text { vegetation }\end{array}$ & $\begin{array}{l}\text { Distinction } \\
\text { between } \\
\text { savanna and } \\
\text { forest trees }\end{array}$ & $\begin{array}{l}\text { Tree age } \\
\text { structure }\end{array}$ & $\begin{array}{l}\text { Limiting resources } \\
\text { for vegetation }\end{array}$ & $\begin{array}{l}\text { Stable state(s) (in the absence of } \\
\text { fires) }\end{array}$ \\
\hline $\begin{array}{l}\text { JSBACH/ } \\
\text { DYNVEG }\end{array}$ & No & $\begin{array}{l}\text { LAI, PFT fractions, carbon } \\
\text { in vegetation pools }\end{array}$ & No & No & $\begin{array}{l}\text { Uncolonized space, } \\
\text { hospitable } \\
\text { land (water, indi- } \\
\text { rectly via NPP) }\end{array}$ & $\begin{array}{l}\text { Dominant woody (tree, shrub) } \\
\text { PFTs }\end{array}$ \\
\hline $\begin{array}{l}\text { LPJ- } \\
\text { GUESS- } \\
\text { SPITFIRE }\end{array}$ & No & $\begin{array}{l}\text { Individual-based model. } \\
\text { LAI, PFT fractions, carbon } \\
\text { in vegetation pools }\end{array}$ & Yes & Yes & Water and light & $\begin{array}{l}\text { Depending on climate (mainly } \\
\text { precipitation), either forest } \\
\text { or grassland is the stable } \\
\text { state. Savanna is observed in } \\
\text { a relatively small precipitation } \\
\text { range. }\end{array}$ \\
\hline aDGVM & Yes & $\begin{array}{l}\text { Individual-based model. } \\
\text { Plant level: LAI, height, } \\
\text { basal area, canopy area, } \\
\text { biomass in different pools } \\
\text { Stand level: LAI, PFT } \\
\text { fractions, carbon in vegeta- } \\
\text { tion pools of different PFTs, } \\
\text { basal area, tree cover }\end{array}$ & Yes & Yes & $\begin{array}{l}\text { Water, light, } \\
\text { (space, via light } \\
\text { competition) }\end{array}$ & $\begin{array}{l}\text { Depending on climate } \\
\text { (mostly defined by precipi- } \\
\text { tation): desert, grassland, } \\
\text { savanna, forest }\end{array}$ \\
\hline
\end{tabular}

Table 1. Continued.

\begin{tabular}{|c|c|c|c|c|c|}
\hline Model & How is fire represented? & $\begin{array}{l}\text { Mechanisms } \\
\text { driving } \\
\text { savanna }\end{array}$ & $\begin{array}{l}\text { Mechanisms driving } \\
\text { forest/grassland presence }\end{array}$ & $\begin{array}{l}\text { Would a } \mathrm{CO}_{2} \text { increase modify the } \\
\text { tree-grass transition and how? }\end{array}$ & Reference \\
\hline $\begin{array}{l}\text { JSBACH/ } \\
\text { DYNVEG }\end{array}$ & $\begin{array}{l}\text { Fire is a function of air humidity and litter. } \\
\text { Fires are mainly fostered by trees, which } \\
\text { are also damaged by fire (negative feed- } \\
\text { back) }\end{array}$ & Fires & $\begin{array}{l}\text { Forest presence in the absence of fires } \\
\text { (at any climate), while grasslands ap- } \\
\text { pear at high frequency of fire occur- } \\
\text { rence, i.e., at very intense dryness }\end{array}$ & $\begin{array}{l}\text { Only indirectly (by changing litter } \\
\text { availability for wildfires) }\end{array}$ & $\begin{array}{l}\text { Brovkin et al. (2009); } \\
\text { Reick et al. (2013) }\end{array}$ \\
\hline $\begin{array}{l}\text { LPJ- } \\
\text { GUESS- } \\
\text { SPITFIRE }\end{array}$ & $\begin{array}{l}\text { Fire is prescribed by remote sensing but } \\
\text { its effects on vegetation depend on fuel } \\
\text { availability and environmental conditions. } \\
\text { Fires are fostered by both woody and grass } \\
\text { biomass }\end{array}$ & $\begin{array}{l}\text { Fires, water } \\
\text { competition }\end{array}$ & $\begin{array}{l}\text { Forests presence given sufficient pre- } \\
\text { cipitation, while grasslands appear at } \\
\text { high frequency of fire occurrence, or } \\
\text { low precipitation. }\end{array}$ & $\begin{array}{l}\text { Higher } \mathrm{CO}_{2} \text { would benefit } \mathrm{C}_{3} \text { veg- } \\
\text { etation (trees) as compared to } \mathrm{C}_{4} \\
\text { grasses. At the same time though, } \\
\text { grasses and trees would produce more } \\
\text { litter, which would increase fire inten- } \\
\text { sity and hence might have negative ef- } \\
\text { fects on trees. }\end{array}$ & $\begin{array}{l}\text { Smith et al. (2001); } \\
\text { Thonicke et al. (2010) }\end{array}$ \\
\hline aDGVM & $\begin{array}{l}\text { Fire intensity is defined by fuel moisture } \\
\text { and fuel biomass; fire ignition probability is } \\
\text { a constant; fire removes aboveground grass } \\
\text { biomass and, depending on height, above- } \\
\text { ground tree biomass (topkill); vegetation } \\
\text { can re-sprout. Grasses foster fire spread and } \\
\text { benefit from recurrent fires (positive feed- } \\
\text { back). }\end{array}$ & $\begin{array}{l}\text { Competition } \\
\text { for water, fires }\end{array}$ & $\begin{array}{l}\text { Forest presence at high rainfall lev- } \\
\text { els (where fire is not possible) and at } \\
\text { mesic conditions when fire is absent; } \\
\text { grassland presence at more arid con- } \\
\text { ditions when precipitation does not } \\
\text { allow tree growth, and at more mesic } \\
\text { conditions in the presence of fire. }\end{array}$ & $\begin{array}{l}\mathrm{CO}_{2} \text { fertilization promotes tree } \\
\text { growth and (1) grasslands are trans- } \\
\text { formed into savannas and (2) tree } \\
\text { canopy closure in savannas sup- } \\
\text { presses grass growth and fire activity, } \\
\text { such that savannas are transformed } \\
\text { into forests }\end{array}$ & $\begin{array}{l}\text { Scheiter and } \\
\text { Higgins (2009); } \\
\text { Scheiter et al. (2012) }\end{array}$ \\
\hline
\end{tabular}

driven by external forcing, such as climate and $\mathrm{CO}_{2}$ changes, without being coupled to a general circulation model, and thus without feeding back to the climate. The models used in this study have intrinsic limitations; for example, they all neglect nutrient cycling. A summary of the ecological interactions important in tropical areas and included in the models is presented in Table 1.

\subsubsection{JSBACH (DYNVEG)}

DYNVEG (Brovkin et al., 2009; Reick et al., 2013) is the submodel for vegetation dynamics implemented in the land surface component JSBACH (Raddatz et al., 2007) of the
Max Planck Institute - Earth System Model (MPI-ESM, Giorgetta et al., 2013). DYNVEG groups its various PFTs into a grass class $\left(\mathrm{C}_{3}\right.$ and $\mathrm{C}_{4}$ grasses) and a woody class (trees and shrubs). Within the woody class, DYNVEG distinguishes between two PFTs for tropical trees with different photosynthetic abilities, which nonetheless do not have different fire or shade tolerances, so they do not correspond to what we call savanna and forest tree in this paper. DYNVEG assumes dominance of the woody over the grass class, i.e., trees have a competitive advantage and typically outcompete grasses. Within a class, the competition among PFTs is indirect via NPP: a PFT with higher NPP outcompetes PFTs 
with lower NPP. All PFTs share the same soil water bucket, and there is no separation of root zones between woody and grass classes. Woody and grass classes compete for newly available habitable space, with woody types outcompeting grasses in the absence of disturbances. The space available for colonization can be only part of the total area, i.e., some parts of the habitat are considered inhospitable. This fraction constitutes a sort of resource limitation to tree development, since it is calculated as a function of the average NPP over the last years of simulations, which in turn depends on water (and other resource) availability (Reick et al., 2013). JSBACH overestimates GPP and NPP in water-stressed conditions (Dalmonech and Zaehle, 2013), which partly explains an overestimation of tree cover fraction in drylands (Brovkin et al., 2013). Elevated $\mathrm{CO}_{2}$ concentration increases water use efficiency of all PFTs.

DYNVEG includes a simple representation of fire disturbance. The fraction of burned area increases with higher amounts of litter (i.e., fuel), mostly produced by woody vegetation and decreasing air humidity (a substitute for litter moisture). As a result, savannas in northern Africa with relatively low air humidity and high productivity frequently burn. After the fire, the burned area is quickly occupied by grasses, while woody cover recovers slowly. Thus, in these transient dynamics, grasses indirectly slow down tree growth. Fire disturbance is the main process that keeps a mixture of trees and grasses in drylands.

\subsubsection{LPJ-GUESS-SPITFIRE}

LPJ-GUESS (Smith et al., 2001) was developed to incorporate forest age structure into LPJ (Sitch et al., 2003), thus simulating gap model behavior and including the competition of different age cohorts for light and water. For each grid cell, LPJ-GUESS simulates a number of replicate patches. For the tropical regions, LPJ-GUESS results in one type of $\left(\mathrm{C}_{4}\right)$ grasses, and two types of tree PFTs, savanna and forest trees, where the former are fire tolerant and shade intolerant, and the latter are fire intolerant and shade tolerant. In LPJGUESS, trees and grasses use common water in a superficial soil layer ( $0.5 \mathrm{~m}$ deep), but trees have part of their roots in a deeper soil layer $(1 \mathrm{~m})$. At high water availability, trees outcompete grasses by limiting light availability.

The fire module SPITFIRE (SPread and InTensity of FIRE, Lehsten et al., 2009; Thonicke et al., 2010) was coupled to LPJ-GUESS to include the role of vegetation fires. The effects of fire, simulated by SPITFIRE, vary for the different demographic stages (or height classes). For each fire, fuel load, wind speed, and a proxy for fuel moisture are used to calculate the rate of spread of a potential fire. The fuel load depends on NPP and decomposition rates, which are both related to climate. Grassy fuels are more flammable (due to their lower fuel bulk density), but trees can accumulate more fuel over years without fire, since they decompose more slowly. Hence if burned at high to medium fire frequency, grasslands provide more fuel than forests, while if forests are allowed to accumulate fuel over longer time periods, they provide higher fuel loads than grasslands. All fires remove the aboveground biomass of all grasses. Low-intensity fires can cause high mortality of all young trees, while the effects of these fires on tall trees are limited for savanna trees and more pronounced for forest trees. In general, damage to trees may be underestimated by SPITFIRE in the current parameterization. In fact, frequent fires lead to high mortality of young (and thus physically small) age cohorts, while the direct effects on old age cohorts are very limited, and only large fires can cause high mortality for highly resistant savanna trees. Further details on the implementation of fire effects on vegetation can be found in Lehsten et al. (2009).

\subsection{3 aDGVM}

The aDGVM (Scheiter and Higgins, 2009) is explicitly designed to study tree-grass dynamics in savannas. While the original version of the model only simulates savanna trees and $\mathrm{C}_{4}$ grasses (Scheiter and Higgins, 2009), an updated version, used for the current paper, simulates $\mathrm{C}_{4}$ grasses, $\mathrm{C}_{3}$ grasses, fire-resistant, shade-intolerant, savanna trees; and fire-sensitive, shade-tolerant forest trees (Scheiter et al., 2012). The model uses an individual-based structure to represent trees. Tree recruitment occurs from seeds, and tree seedlings compete with grasses more directly than adult trees.

Plants compete mostly for water and light. Light competition is modeled by considering the light available to grasses below and between canopies. Hence, once a vegetation stand attains a high tree leaf area index (LAI), grass growth is light limited. In addition, seedlings and small trees are shaded by grasses and by adult trees. Savanna trees suffer more from light limitation than forest trees, which are more shade tolerant. Plants extract water from different soil layers, depending on their rooting depth, which increases with the individual root biomass, until reaching maximum value, typically parameterized as being deeper for trees than for grasses. This allows trees to have exclusive access to water in deep soil layers. A simple bucket scheme is used to simulate water extraction and percolation into deeper soil layers. The extent to which soil moisture limits photosynthesis is calculated as a function of soil moisture in the layers in which the plant has roots. Hence, rooting depth, the amount of water transpired, and drought tolerance (i.e., the ability to withstand a low soil water content) determine the outcome of competition for soil moisture. 
Fire intensity in the aDGVM is a function of the grass fuel load, its moisture content and wind speed (following Higgins et al., 2008). Fire spreads when the fire intensity exceeds a minimum intensity, when a fire ignition event (for example lightning strike) occurs, and when ignition probability is exceeded. Days when ignitions occur are random, the number of ignition events per year is linked to tree cover. Fire is assumed to consume a large proportion of aboveground grass biomass. Aboveground grass biomass burns as a function of the fire intensity. The aDGVM models the probability of stem biomass combustion of individual trees (so-called "topkilled" trees, which remain alive after fire and can resprout from their roots) as being a logistic function of stem height and fire intensity (following Higgins et al., 2000). This function varies with tree type. Topkill rates are higher for forest than for savanna trees, and savanna trees have higher re-sprouting rates than forest trees, which can be killed by a sequence of fires. Fire affects tree mortality only indirectly, by influencing the carbon balance of topkilled trees. The fire sub-model and the topkill model together determine if trees remain trapped in a cycle of topkill and resprouting, or if they can attain larger, fire-resistant sizes. Scheiter and Higgins (2009) illustrated that the aDGVM simulates the current distribution of African biomes well, and that it can simulate biomass observed in a long-term fire manipulation experiment in Kruger National Park, South Africa (Higgins et al., 2007).

\subsection{The model experiment setups}

To simulate current conditions, transient simulations were performed where $\mathrm{CO}_{2}$ increased to $390 \mathrm{ppm}$. The JSBACH run used here was a pre-existing CMIP5 historical simulation under transient forcing from 1850 to 2005, with a horizontal resolution of $1.9 \times 1.9^{\circ}$ (Giorgetta et al., 2013). LPJGUESS-SPITFIRE was driven by a combination of TRMM (Tropical Rainforest Measuring Mission) data for precipitation and NCEP data (Kalnay et al., 1996) for temperature and radiation (for details see Weber et al., 2009). The simulation was run with a spin up of 1000 years, and afterwards the simulation was performed from 1960 to 2007, with resolution of $1 \times 1^{\circ}$. Fire frequency was prescribed at each simulated cell using the MODIS MCD45A burned area product MCD 45 (Roy et al., 2005). LPJ-GUESS-SPITFIRE simulated 100 replicate patches for each of the $1^{\circ}$ cells, and each patch had a probability to burn related to the proportion of burned area calculated from the MODIS burned area product. If the fire was supposed to ignite but fuel moisture was high, the fire started instead on the driest day within a 10day period. Fires spread only if their potential rate of spread was above a certain threshold. Since the patch sizes of each of the replicates were below the average fire size, we simulated the burning of the whole replicate (see Lehsten et al., 2009, for further details). All 100 replicates of the patch were finally averaged to get a representative value for the frac- tional tree cover. The aDGVM used monthly mean climate data from the CRU database (Climatic Research Unit, New et al., 2000), and model resolution was $1 \times 1^{\circ}$. A 100 -year model spin-up was conducted first, to ensure that the model was in equilibrium with the environmental conditions, then vegetation was simulated until 2010. Tree cover was calculated as the sum of the canopy areas of all trees higher than $0.5 \mathrm{~m}$, without neighboring trees that shade (and hide) the tree itself. Tree cover in aDGVM could reach $100 \%$ because of the individual canopy overlaps.

\subsection{Observational data sets}

For the comparison between data and models, we used two different types of tree cover observational data sets that have been recently used to study savanna dynamics. One data set is a collection of tree cover data from savanna field sites from Africa (Sankaran et al., 2005), while the other is derived from remote sensing (MODIS), as used, e.g., in Hirota et al. (2011) and Staver et al. (2011b). In both cases, we selected only the data points between $35^{\circ} \mathrm{S}$ and $15^{\circ} \mathrm{N}$ (following Hirota et al., 2011).

The data set from Sankaran et al. (2005) includes data from 854 field sites across Africa. They gathered data from several sources, with no recent human influence, not situated in riparian or seasonally flooded areas, and where vegetation was sampled on a sufficiently large area ( $>0.25$ ha for plot measurements and $>100 \mathrm{~m}$ for transect sampling). Here, we used projected woody cover and mean annual precipitation. The latter included estimates from field measurements, regional rainfall maps, and fitted climatic grids (see Sankaran et al., 2005 for details). See Fig. 1a for a visualization of the tree cover as a function of mean annual rainfall.

The tree cover data set, derived from remote sensing data, was the result of two combined databases. Tree cover data were obtained from the MODIS woody cover product (MOD44B), developed by Hansen et al. (2003). This product used MODIS images between Oct 2000 and Dec 2001 to calculate the fraction of tree cover, with a spatial resolution of $500 \mathrm{~m}$. To exclude areas highly influenced by humans, we combined this data with the global land cover map (GlobCover 2009) with a high spatial resolution $(300 \mathrm{~m})$. We excluded land cover types that were classified as post-flooding or irrigated croplands; rainfed croplands; mosaic cropland (50-70\%) and vegetation (grassland, shrubland, forest; 20$50 \%$ ); mosaic vegetation (grassland, shrubland, forest 50$70 \%$ ) and cropland (20-50\%); artificial surfaces and associated area (urban areas $>50 \%$ ); water bodies; and permanent snow and ice. The mean annual precipitation was obtained by averaging the 42-year (1961-2002) precipitation record from the CRU project (CRU TS 2.1) with $0.5^{\circ}$ resolution. See Fig. 1b for an illustration of the resulting natural woody cover as a function of mean annual precipitation. We must note here that despite its wide use, this data set for tree cover has received some criticism since maximum tree cover never 

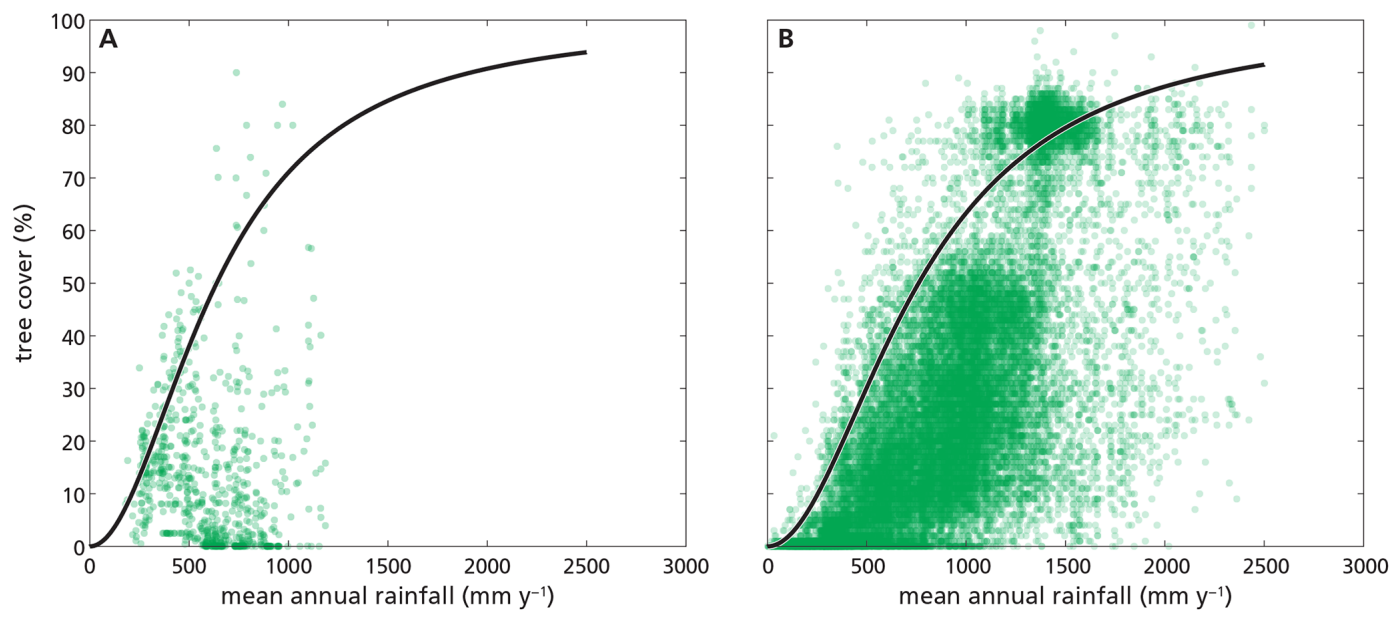

Figure 1. Tree cover as a function of mean annual rainfall $\left(\mathrm{mm} \mathrm{yr}^{-1}\right)$. (a) Savanna field data, reprinted from Sankaran et al. (2005); (b) tree cover obtained from MODIS woody cover product (as in e.g., Hirota et al., 2011), where anthropogenic land use is masked as described in the text. For clarity of representation, we selected only $0.05 \%$ of the data. For both databases, we selected only the data points between $35^{\circ} \mathrm{S}$ and $15^{\circ} \mathrm{N}$ in Africa. The dots are data; the continuous lines are the 90th quantile nonlinear regression (99th quantile not shown; see values of $b$ coefficients in Table S1 in the Supplement). Notice that the field data (a) correspond only to savanna sites, and thus encompass a smaller rainfall range than the satellite data $(\mathbf{b})$.

reaches $100 \%$, even for tropical forests, shrub and small woody plants are under-detected (Bucini and Hanan, 2007), and the observed bimodality between forest and savanna in certain precipitation ranges (Hirota et al., 2011; Staver et al., 2011) might possibly be induced by the algorithm used for vegetation classification (Hanan et al., 2014).

\subsection{Model comparison to observations}

As for the data, for the three models we analyzed the simulated tree cover output (i.e., all woody vegetation) as a function of the corresponding mean annual rainfall conditions, and we select only the points in the African continent between $35^{\circ} \mathrm{S}$ and $15^{\circ} \mathrm{N}$. We masked land use and we used both vegetation and precipitation averaged over 30 years. To evaluate the effect of rainfall on the upper limit of tree cover, following, e.g., Sankaran et al. (2005), we used nonlinear quantile regression (Koenker and Park, 1996), as implemented in the "quantreg" library of the R program. We used 0.90 to 0.99 quantiles and we chose the following nonlinear function:

$y=a \frac{x^{2}}{b+x^{2}}$,

where $x$ is the mean annual rainfall, $y$ the estimated quantile regression for percent tree cover, and $a$ the maximum tree cover (setting $a=100 \%$, while $b$ was estimated by the regression).

In the models, the precipitation ranges where grasslands, savannas, and forests were simulated resulted not only from the different representations of vegetation dynamics, but also from the way climate was included. aDGVM and LPJ-
GUESS-SPITFIRE were forced with (different) climate data, while JSBACH was coupled to an atmospheric model. Both the rainfall (NCEP, CRU, and TRMM) data sets and the simulated climate have inevitable biases, and are hard to compare with each other. Therefore, precipitation estimations were not totally comparable, and for this reason, we will compare the models in the parameter space (i.e., vegetation cover versus mean annual rainfall) and not in the geographical space. Also, we will not discuss the exact mean annual rainfall values at which forest, savanna, and grassland are observed, but we mostly refer to ranges of low, medium, or high mean annual rainfall. For these ranges, we will perform a qualitative comparison of the modeled and observed data in the parameter space (i.e., maximum values, spread, distribution).

In addition to mean annual rainfall, other factors, such as temperature (Higgins and Scheiter, 2012) and temporal distribution of rainfall, are known to be important as well for tropical grasslands, savannas, and forests. Rainfall heterogeneity, intermittency, and seasonality affect water availability (D'Onofrio et al., 2014) and fire return times, and are very important predictors of savanna/forest distribution (Lehmann et al., 2011), with rainfall seasonality reducing growth rates (e.g., limiting water availability, Sarmiento, 1984), influencing root-shoot biomass ratio and local cover (Yin et al., 2014a), and increasing fire frequency (Archibald et al., 2009). Nevertheless, these factors have not yet been thoroughly examined in many ecological studies, possibly, among other reasons, because of lack of accurate rainfall data sets in these areas. Therefore, in the following, we will focus only on mean annual rainfall, whose importance has extensively been studied. We separately evaluate arid and semi- 
arid savannas (Sect. 3.1), and humid savannas and forests (Sect. 3.2), analyzing also if and how the ecological interactions are included in the different models. Finally, we discuss the effects of expected future climatic changes on the outcome of tree-grass competition in the three models (Sect. 3.3).

\section{Results and discussion}

\subsection{Arid and semi-arid savannas and grasslands: the role of water limitation}

In the drier African savanna regions, i.e., with mean annual precipitation lower than a value estimated between $650 \mathrm{~mm} \mathrm{yr}^{-1}$ (Sankaran et al., 2005, see also Fig. 1a) and $1000 \mathrm{~mm} \mathrm{yr}^{-1}$ (Staver et al., 2011, see Fig. 1b), observed tree cover displays a maximum value that is lower than full cover. In this range, for a given annual rainfall, multiple values of tree cover are observed, representing either grasslands or more or less closed savannas, but full cover is never reached. The maximum tree cover increases with mean annual rainfall (see 90th quantile regression lines in Fig. 1; similar results are obtained with the 99th quantile regression lines, not shown), i.e., it depends on water availability. Indeed, the main mechanisms governing the ecological interactions include (i) water limitation on tree growth (Higgins et al., 2012); (ii) tree competition with grasses, which have an especially strong competitive impact on tree seedlings (February et al., 2013; Salazar et al., 2012); (iii) fires further reducing woody cover, although savannas are observed anyway, even if fires were excluded, as shown, e.g., with fire exclusion experiments (Higgins et al., 2007).

At first glance, the relation between tree cover and mean annual rainfall simulated by the models (Fig. 2) is similar to that observed in the data (Fig. 1). In JSBACH output, the maximum tree cover increases between zero and $800 \mathrm{~mm} \mathrm{yr}^{-1}$ approximately, where it reaches its largest cover (see 90th quantile regression curve in Fig. 2a; similar results are obtained with the 99th quantile regression lines, not shown). This increase is mostly due to the fact that all the PFTs can colonize only a part of the space, which is calculated dynamically and increased with water availability (although indirectly, via NPP). In addition, fire-related mortality increases with decreasing air humidity, thus representing another source of water-related limitation in drier areas. At the same time, the limitation to tree maximum cover is not likely to be the result of competition with grasses, since trees are assumed to outcompete grasses, and they are affected by some sort of grass competition at low water availability only temporarily e.g., after a fire (see also Fig. 3b). JSBACH has a tendency to overestimate maximum tree cover at very low values of mean annual rainfall $\left(<100 \mathrm{~mm} \mathrm{yr}^{-1}\right)$, as this model is known to overestimate GPP and NPP (Brovkin et al., 2013).
In the LPJ-GUESS-SPITFIRE model output (Fig. 2b), almost no tree cover is observed for mean annual rainfall up to about $300 \mathrm{~mm} \mathrm{yr}^{-1}$. In this precipitation range, modeled trees are water limited and outcompeted by grasses. Compared to the observations, this model seems to limit tree cover in this precipitation range too strongly. Between about 300 and $900 \mathrm{~mm} \mathrm{yr}^{-1}$ annual rainfall, the maximum vegetation cover in LPJ-GUESS-SPITFIRE increases until it reaches a maximum value (about $90 \%$ tree cover, see 90th quantile regression line in Fig. 2b), partly due to water limitation that allows tree-grass coexistence (between about 350 and $650 \mathrm{~mm} \mathrm{yr}^{-1}$, Arneth et al., 2010), and partly due to fires, which further limit tree cover.

In the aDGVM output, the tree cover displays a maximum value that grows with precipitation between zero and about $500 \mathrm{~mm} \mathrm{yr}^{-1}$ (Fig. 2c). In this range, modeled trees are water limited, while grasses are better competitors in these drier conditions, thus further reducing the tree cover, which would be higher if the model were run without grasses (not shown). The aDGVM and LPJ-GUESS-SPITFIRE include differential rooting depths for individuals, depending on their root biomass, and therefore both models also represent water competition between grasses and tree seedlings. This competition is known to be important for tree-grass coexistence (Hanan et al., 2008; Sankaran et al., 2004), while adult trees have deeper roots that make them better competitors in more humid environments (see Fig. 3a and c, respectively).

\subsection{Humid savannas and forests: the role of fire}

In more humid conditions, bimodality of vegetation cover below and above $60 \%$ is observed in the MODIS data for precipitation in a range between around 1000 and $2000 \mathrm{~mm} \mathrm{yr}^{-1}$ (e.g., Hirota et al., 2011; Staver et al., 2011b, see also Fig. 1b), i.e., clusters with low and high tree cover values are observed, corresponding to a bimodality of savanna and forest cover. Although the validity of this result still needs further investigation (Hanan et al., 2014), this bimodality has been linked to the vegetation-fire feedback, possibly leading to bistability of savanna and forest in this range, as shown using simple models (e.g., van Nes et al., 2014; Staver and Levin, 2012). In brief, grass, particularly abundant in these wet areas, becomes an extremely good fuel in the dry season, which promotes fire occurrence (i.e., the grass-fire feedback, Higgins et al., 2008; Trollope, 1984). When fire occurs, aboveground biomass of all plants is removed. Established savanna trees and grasses can resprout after fire, but tree seedlings are subject to high mortality rates and many forest tree species cannot resprout. Together with grasses, which regrow quickly in the open space after fires, savanna trees benefit from removal of forest tree competitors, (Ratnam et al., 2011; Hoffmann et al., 2012) leading to a stable savanna biome at intermediate rainfall values. However, environmental conditions would allow for forests in the absence of fire (e.g., Staver and Levin, 2012). Figure 3a pro- 

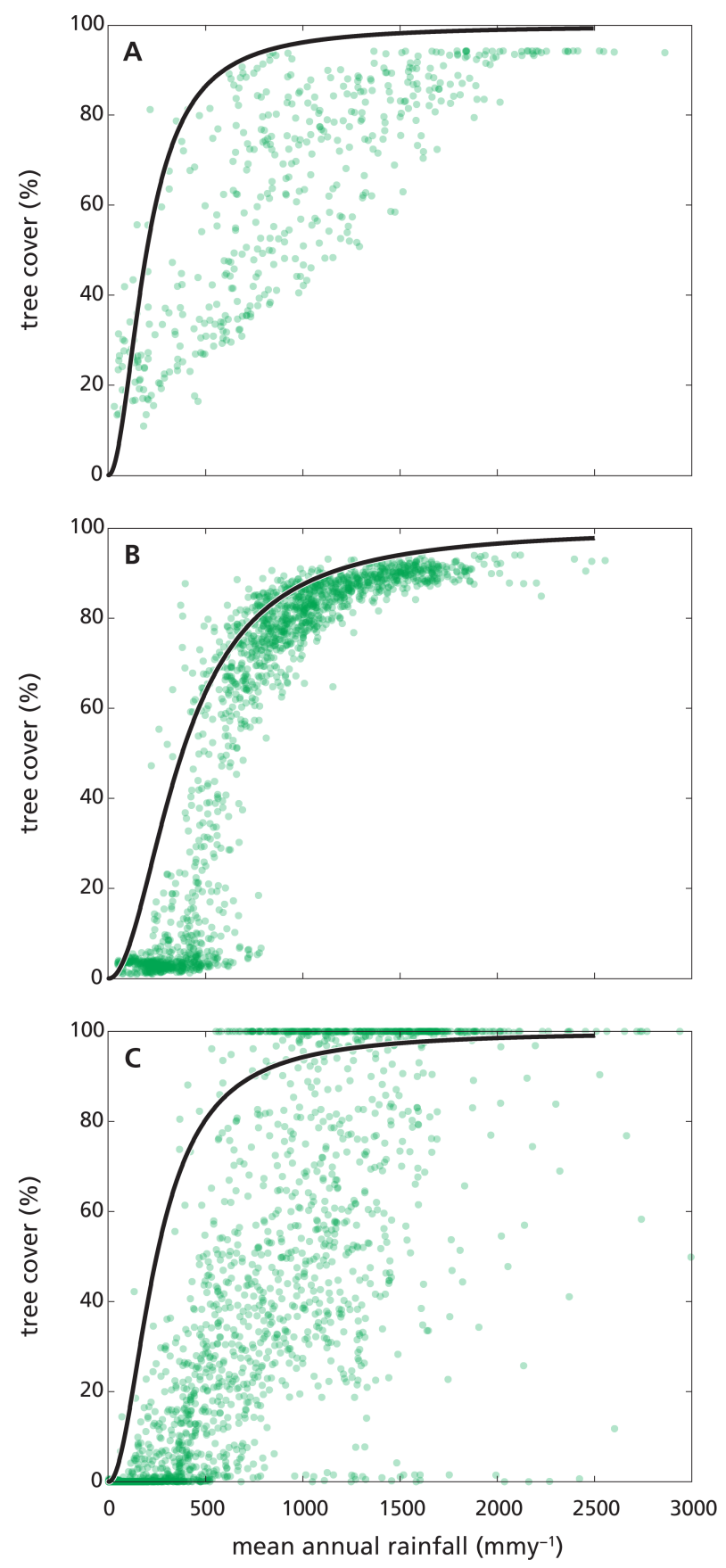

Figure 2. Model outputs for tree cover as a function of mean annual rainfall $\left(\mathrm{mm} \mathrm{yr}^{-1}\right)$ in Africa between $35^{\circ} \mathrm{S}$ and $15^{\circ} \mathrm{N}$ : (a) JSBACH; (b) LPJ-GUESS-SPITFIRE; (c) aDGVM. The dots are data, the continuous lines are the 90th quantile nonlinear regression (99th quantile not shown; see value of $b$ coefficients in Table S1 in the Supplement).

vides a schematic diagram of this feedback. At the highest end of the rainfall range, fires are totally suppressed and only forests are observed, since grass growth is inhibited by tree shade.
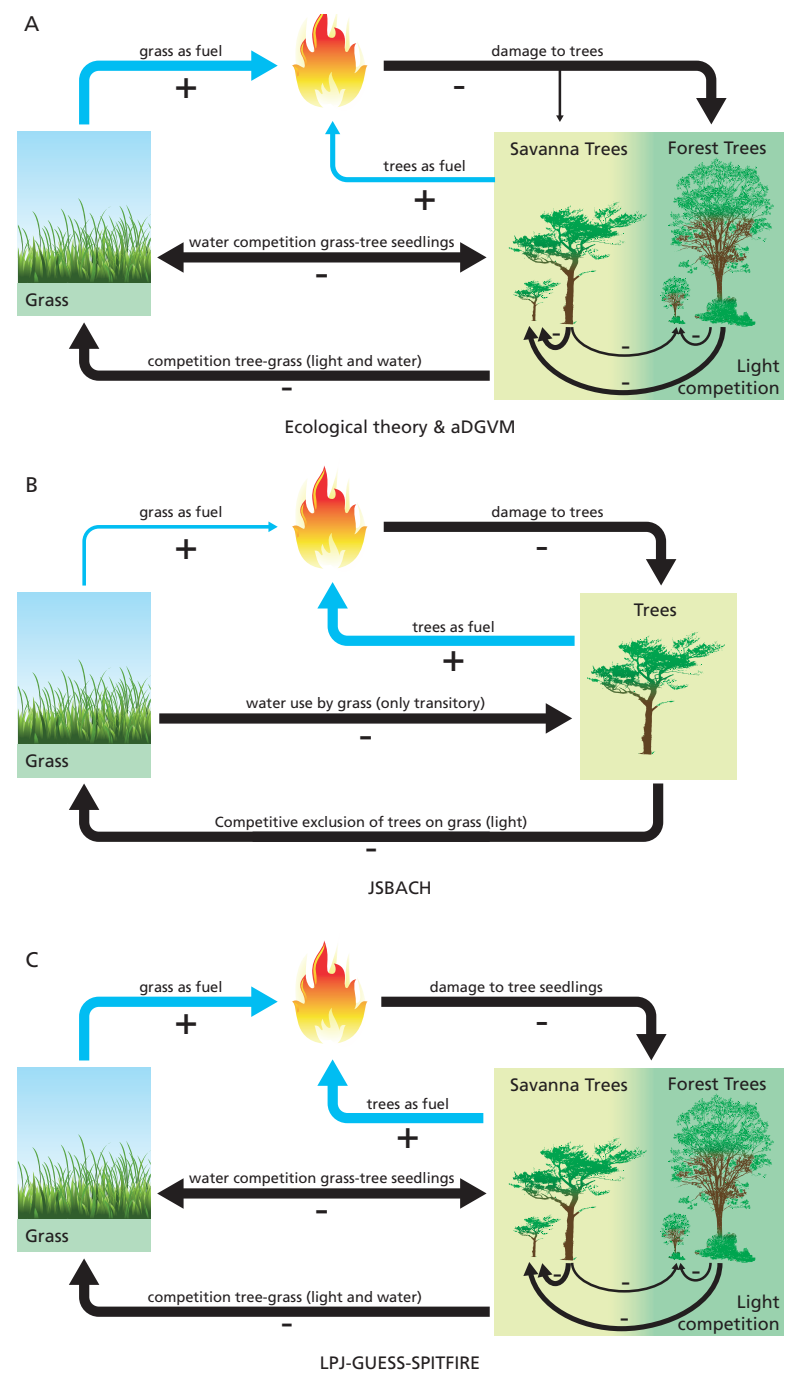

Figure 3. Schematic diagram of the main ecological interactions that determine the forest-savanna-grassland transition, according to (a) Ecological theory and the aDGVM; (b) JSBACH; (c) LPJGUESS-SPITFIRE. Light arrows represent positive effects, dark arrows negative effects. The aDGVM (a) was designed to include the key ecological mechanisms known from theory, namely that grasses increasing fire spread (positive feedback), the distinction between forest and savanna trees (with fires damaging forest tree mostly, shade-intolerant savanna seedlings and shade-tolerant forest seedlings), separate resource competition between trees and grasses depending on their size (grasses and tree seedlings compete for the same water, while adult trees outcompete grasses for both water and light). JSBACH (b) includes fires as mainly fostered by the litter of trees, which are also mainly damaged by fire (negative feedback). Trees competitively exclude grasses, although temporarily after disturbances grasses also compete with them for the same water. LPJGUESS-SPITFIRE (c) is on one hand similar to the aDGVM, since it distinguishes between tree life stages and it separates savanna and forest trees, with analogous representation of water and light treegrass competition. On the other hand, it includes similar effects of tree and grass biomass in fostering fires. 
The role of fire in maintaining savannas in humid environments is included in all of the models, although in different ways. At high precipitation, JSBACH tree cover output displays a constant maximum value (above about $800 \mathrm{~mm} \mathrm{yr}^{-1}$ ), but the data display considerable scattering below full tree cover (Fig. 2a). In other words, the model predicts savannas and forests in this range, but the data do not display bimodality of high and low tree cover values (see Supplement S1). This is a consequence of the fact that in this model fire is triggered more by trees than by grasses, since trees produce larger amounts of litter and thus fuel. Fire favors grasses because it opens the landscape by reducing the tree cover and generates space for them. Thus, fire creates a negative feedback because fewer fires occur when tree cover is lower (Fig. 3b), thus preventing hysteresis and bistability in this model.

LPJ-GUESS-SPITFIRE simulation results do not show any low tree cover value (e.g., below $50 \%$ cover) for rainfall higher than about $900 \mathrm{~mm} \mathrm{yr}^{-1}$ (Fig. 2b). In other words, this model (quite surprisingly) does not predict any savanna in mesic environments. In the model, though fire frequency is prescribed from the satellite data, fire spread depends on fuel load (Fig. 3c) and fuel moisture, and thus unfavorable conditions might still prevent fires. Both grass and tree presence increases fire intensity, opening up space, and thus favoring grasses. This is not strictly a positive grass-fire feedback because grass-free areas can also burn. Thus, as grasses are not fostered by the positive feedback with fire, they are always outcompeted by trees in LPJ-GUESS-SPITFIRE when water availability is high, and they do not survive above approximately $900 \mathrm{~mm} \mathrm{yr}^{-1}$. At the same time, this issue is also likely to be connected to fire intensity depending on fuel moisture. In this model, fire occurrence in a patch is calculated probabilistically from the proportion of burned area as determined from the remote sensing product. If fire occurs in a period of high fuel moisture, the intensity will be limited, thus having little effect on vegetation. This probabilistic approach is necessary because the temporal extent of the remote sensed data (now only ca. 10 years), used to generate the probability of burned area for each pixel, is much shorter than the extent of the climate data for which the model was run (ca. 100 years).

In aDGVM, maximum tree cover values can reach full cover above about $500 \mathrm{~mm} \mathrm{yr}^{-1}$, but the points are still very scattered, and display some clustering at around 30-60\% cover for intermediate rainfall values (Fig. 2c). If we only select points in this rainfall range (e.g., between $800 \mathrm{~mm}$ and $1200 \mathrm{~mm} \mathrm{yr}^{-1}$ ), we observe that the tree cover distribution is bimodal (see Supplement 1; note that this conclusion is robust for different choices of the limits of the rainfall range). aDGVM explicitly includes the grass-fire feedback, which is reinforced by the difference between fire-tolerant savanna trees, and fire-sensitive forest trees (Fig. 3a). When the forest trees suppress the savanna trees and the grasses through light competition, the result is a forest biome with low fire frequency or even fire suppression, primarily due to scarcity of (grass) fuel. At sites with regular fires, forest trees cannot persist, resulting in low forest tree cover and intermediate savanna tree cover, with grasses colonizing open spaces and fostering fire occurrence. This vegetation state represents a savanna biome. In a certain range of environmental (e.g., rainfall) conditions, a system initialized as a forest will not shift to a savanna unless fire ignition probability is high, while a system initialized as a savanna will persist in the same state unless fire ignition probability is very low. As a consequence of including this positive feedback, experiments with the aDGVM show that fire suppression can lead to transitions and hysteresis between savanna and forest states (Higgins and Scheiter, 2012; Moncrieff et al., 2013).

Finally, we note that at extremely high rainfall values, when water is not limiting and tree canopies close into a forest, both in LPJ-GUESS-SPITFIRE and aDGVM, trees exclude grasses through light competition (Fig. 2b-c). This mechanism is only implicitly included in JSBACH, and it acts along the whole precipitation gradient giving competitive advantage to trees in general.

\subsection{Effects of future climatic changes}

Hereafter we discuss results from two simple conceptual experiments (namely increasing $\mathrm{CO}_{2}$ concentrations and decreasing precipitation) to illustrate how the different representations of the ecological interactions in the three DGVMs could lead to different predictions of the state of the grassland-savanna-forest transition under future climatic changes.

Expected increase in $\mathrm{CO}_{2}$ concentration in the future is likely to affect the outcome of tree-grass competition, mediating both important mechanisms we discussed so far, i.e., competition for water and fires. Fire is expected to decrease under increased $\mathrm{CO}_{2}$ level because of the decrease in grass fuel load, given that $\mathrm{C}_{3}$ woody plants are favored over $\mathrm{C}_{4}$ grasses under elevated $\mathrm{CO}_{2}$ levels (Ehleringer et al., 1997). In JSBACH, higher $\mathrm{CO}_{2}$ leads to higher productivity of grasses and trees, which in turn increases fire spread and hence introduces a negative feedback, dampening the increase of tree biomass. In aDGVM, $\mathrm{CO}_{2}$ fertilization promotes tree growth, and thus tree establishment in grasslands, transforming them into savannas or woodlands (with or without fire, respectively). So in contrast to JSBACH, aDGVM includes a positive feedback, leading to tree canopy closure in savannas, which, suppressing grass growth, also reduces fire activity, transforming them into woodlands and forests (Scheiter and Higgins, 2009). Due to this positive feedback, $\mathrm{CO}_{2}$ concentration can induce hysteresis effects on the vegetation states (Higgins and Scheiter, 2012). LPJ-GUESS-SPITFIRE shows intermediate behavior between the other two models because grass and woody vegetation contribute similarly to fuel formation. Also, since in this model fire frequency is prescribed from remotely sensed data, any effects of changes of $\mathrm{CO}_{2}$ 
levels on fire occurrence would be very limited, though there might be pronounced effects on resulting vegetation composition.

Another consequence of climate change is a possible decrease in precipitation. This scenario also leads to different model behavior. In JSBACH and LPJ-GUESS-SPITFIRE, drier conditions lead to lower (woody) biomass productivity, but the impact on fire spread differs between these two models. JSBACH predicts no major effects on fire as drier conditions would lead to higher fuel flammability, thus compensating for the impacts of the woody biomass decrease. In LPJ-GUESS-SPITFIRE the decrease in productivity is dominant, and hence a strong decrease of fire frequency is expected (Lehsten et al., 2010). In aDGVM the strong positive feedback would lead to a magnification of the woody vegetation decrease, as lower precipitation leads to increased grass productivity (because of less competition with woody vegetation) and lower humidity, increasing the likelihood of fire occurrence.

In summary, we expect that in JSBACH, LPJ-GUESSSPITFIRE and aDGVM, savanna systems have quite different sensitivities to climate change, and their predictions on the effects of climate change on fire occurrence diverge substantially. Given the importance of fires for estimating the global carbon budget (Le Quéré et al., 2013), this is remarkable, and it illustrates clearly how representing the ecological interactions more or less accurately can lead in some cases to similar results under present conditions (where the models have been tuned), but their predictions can diverge substantially when the models are used for future scenarios.

\subsection{Other mechanisms influencing tropical savannas, grasslands, and forests}

Up to now we considered water limitation and fires as the main drivers of grassland, savanna, and forest distribution. Several additional factors can be important for vegetation dynamics, especially at the local scale. The first factor is herbivory. Browsing (particularly by mega-herbivores in Africa) is known to have an important limiting effect on tree cover, similar to the effects of fire (e.g., Scheiter and Higgins, 2012; Staver et al., 2012), while grazing can favor trees because it limits grass expansion (e.g., Sankaran et al., 2008). However, large herbivores do not seem to be critical in determining forest and savanna distributions (Murphy and Bowman, 2012). Secondly, although it has been observed that savannas can be associated with nutrient poor soils (Lloyd et al., 2008), it is generally accepted that nutrient limitation does not explain the savanna-forest transition (Bond, 2010; Favier et al., 2012; Murphy and Bowman, 2012). For these reasons, and to avoid inconsistencies while evaluating different models, we only used DGVMs that did not include nutrient cycling. Thirdly, vegetation tends to have local spatial dynamics and to feed back to the environment at much smaller spatial scales than the DGVMs' resolution. These local spatial water-vegetation interactions are strictly connected to vegetation resilience in arid and semiarid ecosystems (e.g., Rietkerk et al., 2004), and they can also influence the coexistence of trees and grasses in the most arid savannas (Baudena and Rietkerk, 2013; Nathan et al., 2013). Although the local scale is partly taken into account in some DGVMs by including individual-based dynamics or tiling schemes (that represent different vegetation types and bare soil next to each other within the same cell), these assume a common use of soil and hydrological resources within the grid cell, thus not allowing representation of the local, sub-grid mechanisms, which are fairly difficult to scale up (Rietkerk et al., 2011). Finally, on the African continent the vast majority of fires are ignited by humans (Archibald et al., 2009; Saarnak, 2001), although their decisions on when to burn an area, as well as the fire spread and intensity, are still related to fuel composition (Govender et al., 2006). Humans maintain the grass-fire feedback, since they aim to keep the land free of woody vegetation, and also because fire spread is favored by grass presence (Ratnam et al., 2011). Changes in land use have therefore strong influences on the current and future outcomes of tree-grass competition. Also, humans are expected to change their application of fire as a land use tool, as a consequence of changed environmental conditions. These elements are partly taken into account in some DGVMs (e.g., in LPJ-GUESSSPITFIRE), but we do not consider them here for the purpose of this paper.

\section{Concluding remarks}

Current ecological understanding identifies water limitation and grass-fire feedback as dominant mechanisms driving the forest-savanna-grassland transition in Africa. In arid and semiarid savannas, trees are water limited, and the water competition with grasses is the key factor determining savanna existence. In these conditions, grasses compete particularly fiercely with tree seedlings. In wetter areas along the climatic gradient, savannas are maintained by the presence of a positive grass-fire feedback. Fire spread is increased by grasses, which provide fuel load. Grasses re-grow faster than trees after fires, while tree recruitment is limited. Thus, trees do not close their canopies, leaving more free space for grasses. On the other hand, when trees manage to close their canopies, grasses are outcompeted because of light limitations, and because fire is suppressed. This grass-fire feedback is reinforced by the higher flammability of forest trees with respect to savanna trees. Both water limitations and fires act differently on tree adults and seedlings, which compete more directly with grasses and are the most sensitive stage in tree life.

These mechanisms are to varying extents included in the three DGVMs we analyzed (JSBACH, LPJ-GUESSSPITFIRE and aDGVM). Indeed, the three models predict the main features of the current tree cover along the mean an- 
nual rainfall gradient in Africa, as derived from ground and satellite observations. aDGVM output matches the observations better than the other two models. This is perhaps to be expected since this model is specifically designed for African vegetation and it includes more detailed representations of ecological interactions, especially the vegetation-fire feedback. For the other two models, the main differences between observations and model outputs are (i) JSBACH overestimates tree cover in dry areas (see also Brovkin et al., 2013); (ii) LPJ-GUESS-SPITFIRE does not show any savanna at medium to high annual rainfall rates; (iii) both these DGVMs do not show bimodality of savannas and forests in humid areas. This latter point might feed the debate over whether or not bimodality between savanna and forest cover actually exists (see, e.g., Hanan et al., 2014). Despite their reasonably good performances, not all the mechanisms included in JSBACH and LPJ-GUESS-SPITFIRE are fully appropriate to represent vegetation in the tropics and subtropics. In JSBACH, competition between trees and grasses favors the former irrespectively of water availability, which is one of the reasons behind JSBACH tree cover overestimation. At the same time, in this model, fire is fostered disproportionately by woody vegetation as compared to grasses, resulting in a negative feedback. This is responsible for observing savannas in larger parts of the rainfall gradients, and no savannas would be simulated without them. Although the three models display comparable outcomes under the current climate, the negative fire-vegetation feedback in JSBACH, the positive feedback in aDGVM, and the intermediate behavior of LPJ-GUESS-SPITFIRE lead to different predictions of fire frequency and effects under climate change scenarios between the three models. In JSBACH, the initial increase in woody vegetation due to higher $\mathrm{CO}_{2}$ concentrations, would be dampened by the consequent increase in fire spread. It is interesting that the sensitivity to shifts between forests and savannas is low for JSBACH as negative feedbacks are more important, while in aDGVM the positive grass-fire feedback mechanism results in a large sensitivity to shifts of the different tree-grass systems. LPJ-GUESS-SPITFIRE shows intermediate behavior between the other two models, since grass and woody vegetation foster fire in a similar way. Also, in this model, fires seem to be suppressed too easily by high humidity conditions, which cause savannas to be absent at medium-high annual rainfall values.

Tree seedlings are the bottleneck stage of tree life in the forest-savanna-grassland transition (Salazar et al., 2012; Sankaran et al., 2004), and the two most important mechanisms we identified here, i.e., fires and water competition and limitation tend to affect tree seedlings particularly strongly. Thus, including tree demography, as in LPJ-GUESS and the aDGVM, improves the representation of ecological interactions in the models. Also, representing forest and savanna trees with different flammability and shade tolerances (as in LPJ-GUESS and aDGVM) is beneficial, and they reinforce the positive grass-fire feedback if included (as in aDGVM).
Having in mind that DGVMs need to be kept as simple as possible, we conclude that the most important mechanisms for better representing the forest-savanna-grassland transition are (i) how water limits tree growth and regulates treegrass competition and (ii) the grass-fire feedback. Distinguishing between tree life stages and representing the different responses of forest and savanna trees are less important features for the models, although they can considerably ameliorate the representation of the two main mechanisms. As parts of these mechanisms are already included in most DGVMs, extensions should be relatively simple, but they can substantially improve the predictions of vegetation dynamics and carbon balance under future climate change scenarios.

\section{The Supplement related to this article is available online at doi:10.5194/bg-12-1833-2015-supplement.}

Acknowledgements. This study was initiated during a TERRABITES workshop in 2010 at INIA-UAH, Madrid. We gratefully acknowledge all of the workshop participants for starting an early discussion on the topic, and V. Gayler and T. Raddatz for kindly preparing the DYNVEG-JSBACH data. We thankfully acknowledge the support of this workshop by TERRABITES COST Action ES0805, which also financed a short-term scientific mission allowing B. Cuesta to begin work on this paper. S. Scheiter acknowledges financial support by the Hessian Landes-Offensive zur Entwicklung Wissenschaftlich-ökonomischer Exzellenz (LOEWE).

Edited by: K. Thonicke

\section{References}

Archibald, S., Roy, D., van Wilgen, B., and Scholes, R. J.: What limits fire? An examination of drivers of burnt area in Southern Africa, Glob. Chang. Biol., 15, 613-630, 2009.

Arneth, A., Lehsten, V., Spessa, A., and Thonicke, K.: Climate-fire interactions and savanna ecosystems: a dynamic vegetation modelling study for the African continent, in: Ecosystem Function in Savannas: Measurement and Modeling at Landscape to Global Scales, edited by: Hill, M. J. and Hanan, N. P., CRC Press, 463479, 2010.

Baudena, M. and Rietkerk, M.: Complexity and coexistence in a simple spatial model for arid savanna ecosystems, Theor. Ecol., 6, 131-141, 2013.

Baudena, M., D'Andrea, F., and Provenzale, A.: An idealized model for tree-grass coexistence in savannas: the role of life stage structure and fire disturbances, J. Ecol., 98, 74-80, 2010.

Beerling, D. J. and Osborne, C. P.: The origin of the savanna biome, Glob. Chang. Biol., 12, 2023-2031, 2006.

Bonan, G. B. and Shugart, H. H.: Environmental factors and ecological processes in boreal forests, Annu. Rev. Ecol. Syst., 20, $1-28,1989$. 
Bonan, G. B., Levis, S., Sitch, S., Vertenstein, M., and Oleson, K. W.: A dynamic global vegetation model for use with climate models: concepts and description of simulated vegetation dynamics, Glob. Chang. Biol., 9, 1543-1566, 2003.

Bond, W. J.: What Limits Trees in $\mathrm{C}_{4}$ Grasslands and Savannas?, Annu. Rev. Ecol. Evol. Syst., 39, 641-659, 2008.

Bond, W. J.: Do nutrient-poor soils inhibit development of forests? A nutrient stock analysis, Plant Soil, 334, 47-60, 2010.

Bond, W. J. and Midgley, G. F.: A proposed $\mathrm{CO}_{2}$-controlled mechanism of woody plant invasion in grasslands and savannas, Glob. Chang. Biol., 6, 865-869, 2000.

Bond, W. J., Midgley, G. F., and Woodward, F. I.: The importance of low atmospheric $\mathrm{CO} 2$ and fire in promoting the spread of grasslands and savannas, Glob. Chang. Biol., 9, 973-982, 2003.

Bowman, D. M. J. S., Murphy, B. P., and Banfai, D. S.: Has global environmental change caused monsoon rainforests to expand in the australian monsoon tropics?, Landsc. Ecol., 25, 1247-1260, 2010.

Brovkin, V., Raddatz, T., Reick, C. H., Claussen, M., and Gayler, V.: Global biogeophysical interactions between forest and climate, Geophys. Res. Lett., 36, 1-6, 2009.

Brovkin, V., Boysen, L., Arora, V. K., Boisier, J. P., Cadule, P., Chini, L., Claussen, M., Friedlingstein, P., Gayler, V., van den Hurk, B. J. J. M., Hurtt, G. C., Jones, C. D., Kato, E., de NobletDucoudré, N., Pacifico, F., Pongratz, J., and Weiss, M.: Effect of Anthropogenic Land-Use and Land-Cover Changes on Climate and Land Carbon Storage in CMIP5 Projections for the TwentyFirst Century, J. Clim., 26, 6859-6881, 2013.

Bucini, G. and Hanan, N. P.: A continental-scale analysis of tree cover in African savannas, Glob. Ecol. Biogeogr., 16, 593-605, 2007.

Buitenwerf, R., Bond, W. J., Stevens, N., and Trollope, W. S. W.: Increased tree densities in South African savannas: $>50$ years of data suggests $\mathrm{CO}_{2}$ as a driver, Glob. Chang. Biol., 18, 675-684, 2012.

Cramer, W., Bondeau, A., Woodward, F. I., Prentice, I. C., Betts, R. A., Brovkin, V., Cox, P. M., Fisher, V., Foley, J. A., Friend, A. D., Kucharik, C., Lomas, M. R., Ramankutty, N., Sitch, S., Smith, B., White, A., and Young-Molling, C.: Global response of terrestrial ecosystem structure and function to $\mathrm{CO}_{2}$ and climate change: results from six dynamic global vegetation models, Glob. Chang. Biol., 7, 357-373, 2001.

Dalmonech, D. and Zaehle, S.: Towards a more objective evaluation of modelled land-carbon trends using atmospheric $\mathrm{CO}_{2}$ and satellite-based vegetation activity observations, Biogeosciences, 10, 4189-4210, doi:10.5194/bg-10-4189-2013, 2013.

De Boer, H. J., Lammertsma, E. I., Wagner-Cremer, F., Wassen, M. J., Dilcher, D. L., and Dekker, S. C.: Climate forcing due to optimization of maximal leaf conductance in subtropical vegetation, Proc. Natl. Acad. Sci. USA, 108, 4041-4046, 2011.

D’Onofrio, D., Baudena, M., D’Andrea, F., Rietkerk, M., and Provenzale, A.: Tree-grass competition for soil water in arid and semiarid savannas: The role of rainfall intermittency, Water Resour. Res., 51, 169-181, doi:10.1002/2014WR015515, 2014.

Donohue, R. J., Roderick, M. L., McVicar, T. R., and Farquhar, G. D.: Impact of $\mathrm{CO}_{2}$ fertilization on maximum foliage cover across the globe's warm, arid environments, Geophys. Res. Lett., 40, 3031-3035, 2013.
Ehleringer, J. R., Cerling, T. E., and Helliker, B. R.: $\mathrm{C}_{4}$ photosynthesis, atmospheric $\mathrm{CO}_{2}$, and climate, Oecologia, 112, 285-299, 1997.

Favier, C., Aleman, J., Bremond, L., Dubois, M. A., Freycon, V., and Yangakola, J.-M.: Abrupt shifts in African savanna tree cover along a climatic gradient, Glob. Ecol. Biogeogr., 21, 787-797, 2012.

February, E. C. and Higgins, S. I.: The distribution of tree and grass roots in savannas in relation to soil nitrogen and water, South African J. Bot., 76, 517-523, 2010.

February, E. C., Higgins, S. I., Bond, W. J., and Swemmer, L.: Influence of competition and rainfall manipulation on the growth responses of savanna trees and grasses, Ecology, 94, 1155-64, 2013.

Fisher, R., McDowell, N., Purves, D., Moorcroft, P., Sitch, S., Cox, P., Huntingford, C., Meir, P., and Ian Woodward, F.: Assessing uncertainties in a second-generation dynamic vegetation model caused by ecological scale limitations, New Phytol., 187, 666681, 2010.

Giorgetta, M. A., Jungclaus, J., Reick, C. H., Legutke, S., Bader, J., Boettinger, M., Brovkin, V., Crueger, T., Esch, M., Fieg, K., Glushak, K., Gayler, V., Haak, H., Hollweg, H.-D., Ilyina, T., Kinne, S., Kornblueh, L., Matei, D., Mauritsen, T., Mikolajewicz, U., Mueller, W., Notz, D., Pithan, F., Raddatz, T., Rast, S., Redler, R., Roeckner, E., Schmidt, H., Schnur, R., Segschneider, J., Six, K. D., Stockhause, M., Timmreck, C., Wegner, J., Widmann, H., Wieners, K.-H., Claussen, M., Marotzke, J., and Stevens, B.: Climate and carbon cycle changes from 1850 to 2100 in MPI-ESM simulations for the Coupled Model Intercomparison Project phase 5, J. Adv. Model. Earth Syst., 5, 572-597, 2013.

Govender, N., Trollope, W. S. W., and Van Wilgen, B. W.: The effect of fire season, fire frequency, rainfall and management on fire intensity in savanna vegetation in South Africa, J. Appl. Ecol., 43, 748-758, 2006.

Hanan, N. P., Sea, W. B., Dangelmayr, G., and Govender, N.: Do fires in savannas consume woody biomass?, A comment on approaches to modeling savanna dynamics., Am. Nat., 171, 851856, 2008.

Hanan, N. P., Tredennick, A. T., Prihodko, L., Bucini, G., and Dohn, J.: Analysis of stable states in global savannas: is the CART pulling the horse?, Glob. Ecol. Biogeogr., 23, 259-263, 2014.

Hely, C., Bremond, L., Alleaume, S., Smith, B., Sykes, M. T., and Guiot, J.: Sensitivity of African biomes to changes in the precipitation regime, Glob. Ecol. Biogeogr., 15, 258-270, 2006.

Hickler, T., Prentice, I. C., Smith, B., Sykes, M. T., and Zaehle, S.: Implementing plant hydraulic architecture within the LPJ dynamic global vegetation model, Glob. Ecol. Biogeogr., 15, 567577, 2006.

Hickler, T., Fronzek, S., Araújo, M. B., Schweiger, O., Thuiller, W., and Sykes, M. T.: An ecosystem model-based estimate of changes in water availability differs from water proxies that are commonly used in species distribution models, Glob. Ecol. Biogeogr., 18, 304-313, 2009.

Higgins, S. I. and Scheiter, S.: Atmospheric $\mathrm{CO}_{2}$ forces abrupt vegetation shifts locally, but not globally, Nature, 488, 209-212, 2012 . 
Higgins, S. I., Bond, W. J., and Trollope, W. S. W.: Fire, resprouting and variability: a recipe for grass-tree coexistence in savanna, J. Ecol., 88, 213-229, 2000.

Higgins, S. I., Bond, W. J., February, E. C., Bronn, A., EustonBrown, D. I. W., Enslin, B., Govender, N., Rademan, L., O'Regan, S., Potgieter, A. L. F., Scheiter, S., Sowry, R., Trollope, L., and Trollope, W. S. W.: Effects of four decades of fire manipulation on woody vegetation structure in savanna, Ecology, 88, 1119-1125, 2007.

Higgins, S. I., Bond, W. J., Trollope, W. S. W., and Williams, R. J.: Physically motivated empirical models for the spread and intensity of grass fires, Int. J. Wildl. Fire, 17, 595-601, 2008.

Higgins, S. I., Bond, W. J., Combrink, H., Craine, J. M., February, E. C., Govender, N., Lannas, K., Moncreiff, G., and Trollope, W. S. W.: Which traits determine shifts in the abundance of tree species in a fire-prone savanna?, edited by: Vesk, P., J. Ecol., 100, 1400-1410, 2012.

Hirota, M., Holmgren, M., Van Nes, E. H., and Scheffer, M.: Global resilience of tropical forest and savanna to critical transitions, Science, 334, 232-235, 2011.

Hoffmann, W. a, Geiger, E. L., Gotsch, S. G., Rossatto, D. R., Silva, L. C. R., Lau, O. L., Haridasan, M., and Franco, A. C.: Ecological thresholds at the savanna-forest boundary: how plant traits, resources and fire govern the distribution of tropical biomes, Ecol. Lett., 15, 759-68, 2012.

House, J. I., Archer, S., Breshears, D. D., and Scholes, R. J.: Conundrums in mixed woody-herbaceous plant systems, J. Biogeogr., 30, 1763-1777, 2003.

Hutchinson, G. E.: The paradox of the plankton, Am. Nat., 95, 137145,1961

Intergovernmental Panel on Climate Change: Climate Change 2007 - The Physical Science Basis: Working Group I Contribution to the Fourth Assessment Report of the IPCC (Climate Change 2007), Cambridge University Press, 2007.

Kalnay, E., Kanamitsu, M., Kistler, R., Collins, W., Deaven, D., Gandin, L., Iredell, M., Saha, S., White, G., Woollen, J., Zhu, Y., Chelliah, M., Ebisuzaki, W., Higgins, W., Janowiak, J., Mo, K. C., Ropelewski, C., Wang, J., Leetmaa, A., Reynolds, R., Jenne, R., and Joseph, D.: The NCEP/NCAR 40-year reanalysis project, Bull. Am. Meteorol. Soc., 77, 437-471, 1996.

Kgope, B. S., Bond, W. J., and Midgley, G. F.: Growth responses of African savanna trees implicate atmospheric $\mathrm{CO}_{2}$ as a driver of past and current changes in savanna tree cover, Austral Ecol., 35, 451-463, 2010.

Koenker, R. and Park, B. J.: An interior point algorithm for nonlinear quantile regression, J. Econom., 71, 265-283, 1996.

Kulmatiski, A. and Beard, K. H.: Root niche partitioning among grasses, saplings, and trees measured using a tracer technique, Oecologia, 171, 25-37, 2013.

Lehmann, C. E. R., Archibald, S. A., Hoffmann, W. A., and Bond, W. J.: Deciphering the distribution of the savanna biome, New Phytol., 191, 197-209, 2011.

Lehmann, C. E. R., Anderson, T. M., Sankaran, M., Higgins, S. I., Archibald, S., Hoffmann, W. A., Hanan, N. P., Williams, R. J., Fensham, R. J., Felfili, J., Hutley, L. B., Ratnam, J., San Jose, J., Montes, R., Franklin, D., Russell-Smith, J., Ryan, C. M., Durigan, G., Hiernaux, P., Haidar, R., Bowman, D. M. J. S., and Bond, W. J.: Savanna Vegetation-Fire-Climate Relationships Differ Among Continents, Science, 343, 548-552, 2014.
Lehsten, V., Tansey, K., Balzter, H., Thonicke, K., Spessa, A., Weber, U., Smith, B., and Arneth, A.: Estimating carbon emissions from African wildfires, Biogeosciences, 6, 349-360, doi:10.5194/bg-6-349-2009, 2009.

Lehsten, V., Harmand, P., Palumbo, I., and Arneth, A.: Modelling burned area in Africa, Biogeosciences, 7, 3199-3214, doi:10.5194/bg-7-3199-2010, 2010.

Le Quéré, C., Andres, R. J., Boden, T., Conway, T., Houghton, R. A., House, J. I., Marland, G., Peters, G. P., van der Werf, G. R., Ahlström, A., Andrew, R. M., Bopp, L., Canadell, J. G., Ciais, P., Doney, S. C., Enright, C., Friedlingstein, P., Huntingford, C., Jain, A. K., Jourdain, C., Kato, E., Keeling, R. F., Klein Goldewijk, K., Levis, S., Levy, P., Lomas, M., Poulter, B., Raupach, M. R., Schwinger, J., Sitch, S., Stocker, B. D., Viovy, N., Zaehle, S., and Zeng, N.: The global carbon budget 1959-2011, Earth Syst. Sci. Data, 5, 165-185, doi:10.5194/essd-5-165-2013, 2013.

Lloyd, J., Bird, M. I., Vellen, L., Miranda, A. C., Veenendaal, E. M., Djagbletey, G., Miranda, H. S., Cook, G., and Farquhar, G. D.: Contributions of woody and herbaceous vegetation to tropical savanna ecosystem productivity: a quasi-global estimate, Tree Physiol., 28, 451-68, 2008.

Moncrieff, G. R., Scheiter, S., Bond, W. J., and Higgins, S. I.: Increasing atmospheric $\mathrm{CO}_{2}$ overrides the historical legacy of multiple stable biome states in Africa, New Phytol., 201, 908-15, 2013.

Murphy, B. P. and Bowman, D. M. J. S.: What controls the distribution of tropical forest and savanna?, Ecol. Lett., 15, 748-58, 2012.

Nathan, J., von Hardenberg, J., and Meron, E.: Spatial instabilities untie the exclusion-principle constraint on species coexistence, J. Theor. Biol., 335, 198-204, 2013.

New, M., Lister, D., Hulme, M., and Makin, I.: A high-resolution data set of surface climate over global land areas, Clim. Res., 21, 1-25, 2000.

Polley, H. W., Johnson, H. B., and Mayeux, H. S.: Increasing $\mathrm{CO}_{2}-$ comparative responses of the c-4 grass Schizachyrium and grassland invader Prosopis, Ecology, 75, 976-988, 1994.

Raddatz, T. J., Reick, C. H., Knorr, W., Kattge, J., Roeckner, E., Schnur, R., Schnitzler, K.-G., Wetzel, P., and Jungclaus, J.: Will the tropical land biosphere dominate the climate-carbon cycle feedback during the twenty-first century?, Clim. Dynam., 29, 565-574, 2007.

Ratnam, J., Bond, W. J., Fensham, R. J., Hoffmann, W. A., Archibald, S., Lehmann, C. E. R., Anderson, M. T., Higgins, S. I., and Sankaran, M.: When is a "forest" a savanna, and why does it matter?, Glob. Ecol. Biogeogr., 20, 653-660, 2011.

Reick, C. H., Raddatz, T., Brovkin, V., and Gayler, V.: Representation of natural and anthropogenic land cover change in MPIESM, J. Adv. Model. Earth Syst., 5, 1942-2466, 2013.

Rietkerk, M., Dekker, S. C., de Ruiter, P. C., and van de Koppel, J.: Self-Organized Patchiness and Catastrophic Shifts in Ecosystems, Science, 305, 1926-1929, 2004.

Rietkerk, M., Brovkin, V., van Bodegom, P. M., Claussen, M., Dekker, S. C., Dijkstra, H. A., Goryachkin, S. V., Kabat, P., van Nes, E. H., Neutel, A.-M., Nicholson, S. E., Nobre, C., Petoukhov, V., Provenzale, A., Scheffer, M., and Seneviratne, S. I.: Local ecosystem feedbacks and critical transitions in the climate, Ecol. Complex., 8, 223-228, 2011. 
Rossatto, D. R., Hoffmann, W. A., and Franco, A. C.: Differences in growth patterns between co-occurring forest and savanna trees affect the forest-savanna boundary, Funct. Ecol., 23, 689-698, 2009.

Saarnak, C. F.: A shift from natural to human-driven fire regime: implications for trace-gas emissions, Holocene, 11, 373-375, 2001.

Salazar, A., Goldstein, G., Franco, A. C., and Miralles-wilhelm, F.: Differential seedling establishment of woody plants along a tree density gradient in Neotropical savannas, J. Ecol., 100, 14111421, 2012.

Sankaran, M., Ratnam, J., and Hanan, N. P.: Tree-grass coexistence in savannas revisited - insights from an examination of assumptions and mechanisms invoked in existing models, Ecol. Lett., 7, 480-490, 2004.

Sankaran, M., Hanan, N. P., Scholes, R. J., Ratnam, J., Augustine, D. J., Cade, B. S., Gignoux, J., Higgins, S. I., Le Roux, X., Ludwig, F., Ardo, J., Banyikwa, F., Bronn, A., Bucini, G., Caylor, K. K., Coughenour, M. B., Diouf, A., Ekaya, W., Feral, C. J., February, E. C., Frost, P. G. H., Hiernaux, P., Hrabar, H., Metzger, K. L., Prins, H. H. T., Ringrose, S., Sea, W., Tews, J., Worden, J., and Zambatis, N.: Determinants of woody cover in African savannas, Nature, 438, 846-849, 2005.

Sankaran, M., Ratnam, J., and Hanan, N.: Woody cover in African savannas: the role of resources, fire and herbivory, Glob. Ecol. Biogeogr., 17, 236-245, 2008.

Sarmiento, G.: The Ecology of Neotropical Savannas, Harvard Univ. Press, Cambridge, Mass, 1984.

Sato, H., Itoh, A., and Kohyama, T.: SEIB-DGVM: A new Dynamic Global Vegetation Model using a spatially explicit individualbased approach, Ecol. Modell, 200, 279-307, 2007.

Scheiter, S. and Higgins, S. I.: Impacts of climate change on the vegetation of Africa: an adaptive dynamic vegetation modelling approach, Glob. Chang. Biol., 15, 2224-2246, 2009.

Scheiter, S. and Higgins, S. I.: How many elephants can you fit into a conservation area, Conserv. Lett., 5, 176-185, 2012.

Scheiter, S., Higgins, S. I., Osborne, C. P., Bradshaw, C., Lunt, D., Ripley, B. S., Taylor, L. L., and Beerling, D. J.: Fire and fireadapted vegetation promoted $\mathrm{C} 4$ expansion in the late Miocene, New Phytol., 195, 653-66, 2012.

Scheiter, S., Langan, L., and Higgins, S. I.: Next-generation dynamic global vegetation models?: learning from community ecology, New Phytol., 198, 957-969, 2013.

Scholes, R. J.: Convex Relationships in Ecosystems Containing Mixtures of Trees and Grass, Environ. Resour. Econ., 26, 559$574,2003$.

Scholes, R. J. and Archer, S. R.: Tree-grass interactions in savannas, Annu. Rev. Ecol. Syst., 28, 517-544, 1997.

Scholes, R. J. and Walker, B. H.: An African Savanna: Synthesis of the Nylsvley Study, edited by Cambridge, Cambridge University Press, Cambridge, UK, 1993.

Sitch, S., Smith, B., and Prentice, I.: Evaluation of ecosystem dynamics, plant geography and terrestrial carbon cycling in the LPJ dynamic global vegetation model, Glob. Chang., 9, 161-185, 2003.

Sitch, S., Huntingford, C., Gedney, N., Levy, P. E., Lomas, M., Piao, S. L., Betts, R., Ciais, P., Cox, P., Friedlingstein, P., Jones, C. D., Prentice, I. C., and Woodward, F. I.: Evaluation of the terrestrial carbon cycle, future plant geography and climate-carbon cycle feedbacks using five Dynamic Global Vegetation Models (DGVMs), Glob. Chang. Biol., 14, 2015-2039, 2008.

Smith, B., Prentice, I., and Sykes, M.: Representation of vegetation dynamics in the modelling of terrestrial ecosystems: comparing two contrasting approaches within European climate space, Glob. Ecol., 10, 621-637, 2001.

Snyder, P. K., Delire, C., and Foley, J. A.: Evaluating the influence of different vegetation biomes on the global climate, Clim. Dynam., 23, 279-302, 2004.

Staver, A. C. and Levin, S. A.: Integrating theoretical climate and fire effects on savanna and forest systems., Am. Nat., 180, 21124, 2012.

Staver, A. C., Archibald, S., and Levin, S. A.: The global extent and determinants of savanna and forest as alternative biome states, Science, 334, 230-232, 2011.

Staver, A. C., Bond, W. J., Cramer, M. D., and Wakeling, J. L.: Top-down determinants of niche structure and adaptation among African Acacias, Ecol. Lett., 15, 673-9, 2012.

Thonicke, K., Spessa, A., Prentice, I. C., Harrison, S. P., Dong, L., and Carmona-Moreno, C.: The influence of vegetation, fire spread and fire behaviour on biomass burning and trace gas emissions: results from a process-based model, Biogeosciences, 7, 1991-2011, doi:10.5194/bg-7-1991-2010, 2010.

Tilman, D.: Resource competition and community structure, Princeton University Press, Princeton, New Jersey, USA, 1982.

Trollope, W. S. W.: Fire in savannas, in: Ecological effects of fire of southern African ecosystems, edited by: Booysen, P. D. V. and Tainton, N. M., Springer-Verlag, Berlin, Germany, 199-218, 1984.

Van Langevelde, F., van de Vijver, C. A. D. M., Kumar, L., van de Koppel, J., de Ridder, N., van Andel, J., Skidmore, A. K., Hearne, J. W., Stroosnijder, L., Bond, W. J., Prins, H. H. T., and Rietkerk, M.: Effects of fire and herbivory on the stability of savanna ecosystems, Ecology, 84, 337-350, 2003.

Van Nes, E. H., Hirota, M., Holmgren, M., and Scheffer, M.: Tipping points in tropical tree cover: linking theory to data., Glob. Chang. Biol., 20, 1016-1021, 2014.

Wakeling, J. L., Staver, A. C., and Bond, W. J.: Simply the best: the transition of savanna saplings to trees, Oikos, 120, 1448-1451, 2011.

Walker, B. H. and Noy-Meir, I.: Aspects of stability and resilience of savanna ecosystems, in Tropical savannas, edited by: Huntley, B. J. and Walker, B. H., Springer-Verlag, Berlin, 556-590,1982.

Walter, H.: Natural Savannas, in Ecology of Tropical and Subtropical Vegetation, Oliver and Boyd, Edinburgh, UK, 1971.

Ward, D.: The Biology of Deserts, Oxford University Press, Oxford, UK, 2009.

Ward, D., Wiegand, K., and Getzin, S.: Walter's two-layer hypothesis revisited: back to the roots!, Oecologia, 172, 617-30, 2013.

Weber, U., Jung, M., Reichstein, M., Beer, C., Braakhekke, M. C., Lehsten, V., Ghent, D., Kaduk, J., Viovy, N., Ciais, P., Gobron, N., and Rödenbeck, C.: The interannual variability of Africa's ecosystem productivity: a multi-model analysis, Biogeosciences, 6, 285-295, doi:10.5194/bg-6-285-2009, 2009.

Wigley, B. J., Bond, W. J., and Hoffman, M. T.: Thicket expansion in a South African savanna under divergent land use: local vs. global drivers?, Glob. Chang. Biol., 16, 964-976, 2010. 
Yin, Z., Dekker, S. C., van den Hurk, B. J. J. M., and Dijkstra, H. A.: Bimodality of woody cover and biomass across the precipitation gradient in West Africa, Earth Syst. Dynam., 5, 257-270, doi:10.5194/esd-5-257-2014, 2014a.
Yin, Z., Dekker, S. C., van den Hurk, B. J. J. M., and Dijkstra, H. A.: Effects of vegetation structure on biomass accumulation in a Balanced Optimality Structure Vegetation Model (BOSVM v1.0), Geosci. Model Dev., 7, 821-845, doi:10.5194/gmd-7-821-2014, $2014 b$. 